\title{
Rhizoctonia zeae CAUSANDO PODRIDÃO EM MILHO NO ESTADO DO PARÁ
}

\author{
LUIZ S. POLTRONIERI ${ }^{1}$, DINALDO R. TRINDADE ${ }^{1} \&$ FERNANDO C. ALBUQUERQUE $^{1}$
}

${ }^{1}$ Embrapa Amazônia Oriental, Tv. Dr. Eneas Pinheiro, s/nº, CEP 66095-100, Belém, PA, e-mail: poltroni@cpatu.embrapa.br

(Aceito para publicação em 26/02/2002)

Autor para correspondência: Luiz S. Poltronieri

\section{ABSTRACT \\ Rot of corn caused by Rhizoctonia zeae in the state of Pará, Brazil}

The occurrence of corn rot caused by Rhizoctonia zeae is reported for the first time in the State of Pará, Brazil.

Em agosto de 2001, detectou-se em área de produtor de milho (Zea mays L.) do híbrido CO 32 Dow Agrosciences localizado no município de Paragominas, PA uma doença causando podridão de espigas em mais de $50 \%$ do plantio. Nos estágios iniciais de infecção as espigas apresentavam-se enrugadas e cobertas por um micélio rosa-salmão e em estágios mais avançados cinza-escuro. Amostras de espigas infectadas foram levadas ao laboratório de fitopatologia da Embrapa Amazônia Oriental para isolamento e identificação do provável patógeno. Hifas formadas sobre os grãos foram transferidas para meio de cultura ágar-água e após o crescimento micelial as colônias foram repicadas para placas de Petri contendo meio de cultura BDA e, logo após, incubadas em condições ambientais de laboratório, para obtenção de cultura pura. Cinco dias após o isolamento observou-se a formação de hifas de coloração rosa-salmão e, após 12 dias, esclerodios submersos e superficiais medindo de 0,5 a $1,0 \mathrm{~mm}$ de diâmetro, branco quando jovem, marrom a marrom-escuro quando maduro, as hifas medindo de 4 a $10 \mu \mathrm{m}$ de largura, incialmente hialina e granular e em culturas velhas rosa-salmão, multisepatada e com constrição no septo cujas características correspondem a uma espécie do gênero Rhizoctonia. O isolado foi enviado ao consultor da JICA, Dr. Masaomi Oniki que identificou o agente causal com sendo Rhizoctonia zeae Voorhees sinonimia: Rhizoctonia endophytica var. filicata Saks. \& Vaar; Sclerotium oryzicola Nakata \& Kawamura. A fase teleomorfa dessa espécie foi determinada por Oniki et al (The perfect state of Rhyzoctonia oryzae e R. zeae and anastomosis groups of waitea circinata. Trans. Mycol. Soc. Jpn. 26:189-198.1985) como sendo Waitea circinata. O patógeno foi registrado pela primeira vez afetando milho nos Estados Unidos (Voorhees, R.K.Sclerotial rot of corn caused by Rhizoctonia zeae. Phytophalogy 24:1290-1303. 1934).

Os testes de patogenicidade foram conduzidos em laboratório, onde a temperatura variou de 25 a $32^{\circ} \mathrm{C}$, utilizandose espigas de milho comum. A inoculação foi através da deposição de blocos de micélio em espigas com casca e sem casca. Deixaram-se espigas como testemunha as quais foram inoculadas com discos de BDA sem o fungo. Após a inoculação as espigas foram mantidas em câmara úmida permanente. $\mathrm{O}$ desenvolvimento da infecção deu-se após cinco dias da inoculação, desenvolvendo o apodrecimento da espiga semelhante ao observado em campo. As espigas testemunhas que receberam o mesmo tratamento apresentaram podridão apenas no ferimento. O reisolamento de $R$. zeae comprovou os postulados de Koch. Este é o primeiro relato de R. zeae afetando milho no Brasil.

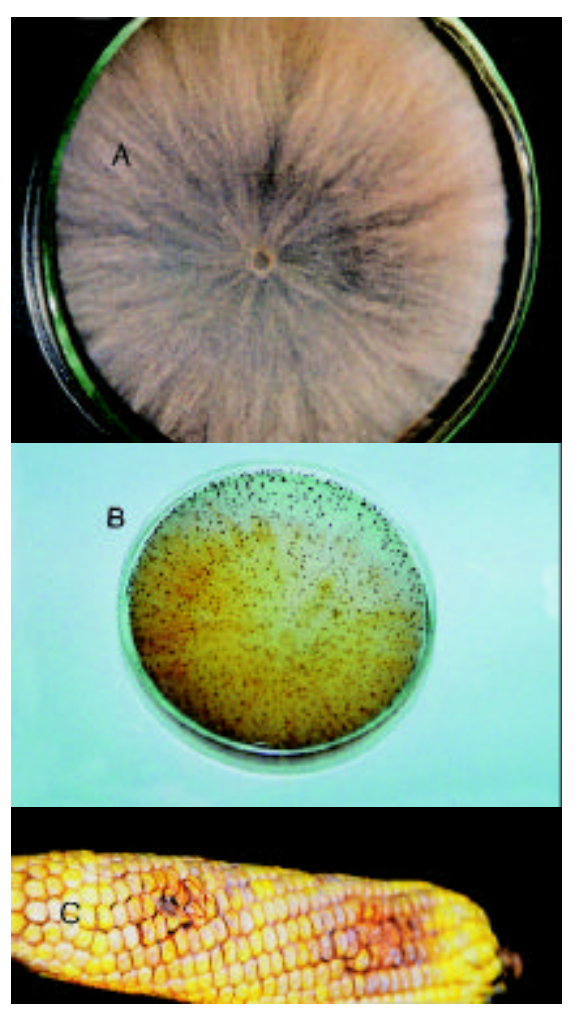

FIG. 1- Rhizoctonia zeae. A - Cultura com cinco dias de idade apresentando micélio de coloração rosasalmão; B - Cultura com 18 dias de idade apresentando numerosos escleródios submersos; $C$ - Sintomas de podridão em espiga de milho (Zea mays). 